\title{
Integrating an anaerobic Bio-nest and an aerobic EMMC process as pretreatment of dairy wastewater for reuse: a pilot plant study
}

\author{
Piyalerg Kongsil · Joshua Lelemia Irvine • \\ P. Y. Yang
}

Received: 21 August 2008/Accepted: 20 February 2009/Published online: 2 April 2009

(C) Springer-Verlag 2009

\begin{abstract}
A large dairy farm located on the island of Oahu, Hawaii was the site for an investigation for the potential integration of the existing facultative lagoon system with a cost effective pretreatment unit process. Based on the results from a laboratory study, a pilot plant was installed with two anaerobic bioreactors $\left(10 \mathrm{~m}^{3}\right.$ each) and one aerobic reactor $\left(3.8 \mathrm{~m}^{3}\right)$. Two layers of media "Bio-nest," providing a void volume of $98 \%$, were placed into each anaerobic bioreactor with $19 \%$ space-based on the bioreactor water volume. For better performance and reduction of shock-load, the equalization/settling tank was employed prior to the first anaerobic Bio-nest reactor. The intermediate holding tank settled effluent suspended solids from the Bio-nest reactor and adjusted the loading rate in order to improve the performance of the aerobic EMMC (entrapped mixed microbial cell) bioreactors. Based on the start-up operation of the Bio-nest system at an organic loading rate of about $1.5 \mathrm{~g} \mathrm{TCOD} / \mathrm{l} / \mathrm{day}$, the production rate of biogas from the first and second Bio-nest reactors was 0.64 and $0.15 \mathrm{l} / 1 / \mathrm{day}$, respectively. This indicates that the anaerobic degradation of organics occurs mainly in the first Bio-nest reactor due to the low loading rate. The removal efficiency from the Bio-nest system shows TCOD removal of about $70 \%$. The EMMC process provided further treatment to achieve a removal efficiency of TCOD at about $50 \%$ and a TN of about $35 \%$. The cost for these pretreatments in order to be integrated with the existing lagoon system is US $\$ 1.1$ per 1,000 gallons $\left(3.8 \mathrm{~m}^{3}\right)$ for dairy wastewater and $\$ 91$ for each ton of TCOD removal.
\end{abstract}

P. Kongsil · J. L. Irvine · P. Y. Yang $(\varangle)$

Graduate Program in Bioengineering,

Department of Molecular Bioscience and Bioengineering, University of Hawai'i at Mānoa, Honolulu, HI 96822, USA

e-mail: pingyi@hawaii.edu
This integration system provides a sustainable improvement of environment and agricultural production.

Keywords Anaerobic Bio-nest · Biogas ·

Dairy wastewater - Entrapped mixed microbial cell .

Existing lagoon

\section{Introduction}

Anaerobic lagoon systems have been applied in many livestock farms for years to manage wastewater (US EPA 1983). Although the lagoon system is considered to be a low cost, low maintenance, easy operation system (Pearson et al. 1987; Mara et al. 1992; Maynard et al. 1999), it still has many problems, such as odor generation, groundwater contamination, surface water pollution, and lagoon sludge clean-out. These problems will be more obvious when an intensified livestock operation is practiced. It is to be expected that poor treatment performance will occur if the designed lagoon volume is under the increased organic loading rate applied. In order to relieve the listed weaknesses of the existing lagoon system, an appropriate, costeffective pretreatment unit process needs to be developed for the integration of existing lagoon system for reuse.

A pilot scale for the potential integration of the existing lagoon system with a cost effective pretreatment unit process was investigated at a large dairy farm located on the island of O'ahu, Hawai'i. Currently, a quantity of $1,136 \mathrm{~m}^{3} /$ day of wastewater is generated from the milk parlor and is discharged into the existing facultative lagoon systems $(72.6 \times 15.2 \times 1.83 \mathrm{~m})$. The wastewater generated from the milking center is mainly composed of milk waste produced by washing milking equipment, walking way flushing waste, and manure flushing waste. 
In the United States there is no strict reuse standard for effluent reuse for flushing of milk parlor facilities. However, as suggested by Crook and Surampalli (1996) acceptable TSS concentration of $<5 \mathrm{mg} / \mathrm{l}$ and $\mathrm{BOD}_{5}$ $<20 \mathrm{mg} / \mathrm{l}$ is suggested for reuse of treated domestic wastewater. Consequently, to meet requirements for agriculture practices a target effluent quality was developed from a previous laboratory study, as shown in Table 1 (Dong 2003) for the practice in the state of Hawai'i.

Additionally, another limitation of current lagoon operation is the persistent maintenance problems of sludge clean-up. Therefore, it was recommended that a pre-treatment unit process must be integrated to this lagoon system to achieve the goals of possible renovation/reuse of the dairy farm wastewater as well as to be better stewards in the protection of environment.

A laboratory bench-scale innovative bioreactor for milk parlor wastewater treatment was developed by Dong (2003). This bioreactor consists of a series of bioreactors with two key wastewater treatment processes: an anaerobic Bio-nest process and an aerobic entrapped mixed microbial cell (EMMC) process.

Dong and Yang (2003) indicate that the anaerobic Bionest process is able to achieve a high solid retention time (SRT) of 110 days because the Bio-nest structure has a high specific area that is able to hold and retain the biomass. Koppar (2005) states the advantages of a Bio-nest reactor is that it encompasses all characteristics of a hybrid reactor combined with the advantages of an anaerobic filter and up-flow anaerobic sludge blanket (UASB). Therefore, the Bio-nest reactor is expected to overcome the operation problems of conventional UASB and anaerobic filters as well as enhance the potential of milk parlor wastewater treatment.

The aerobic EMMC bioreactor was integrated after the anaerobic Bio-nest bioreactor to enhance the removal of residual COD and nutrients. The aerobic EMMC reactor with an intermittent aeration schedule was demonstrated to be an effective method to simultaneously remove carbon and nitrogen from various kinds of the anaerobically treated effluent from dairy, swine, and sugar mill wastewater (Yang et al. 1991, 1997, 2002a, 2003a; Dong 2003).

A series of laboratory scales of the innovative biological pretreatment unit process, including anaerobic "Bio-nest"specially prepared media and aerobic EMMC bioreactors, were investigated for the potential treatment of this wastewater. The final effluent qualities after these series of treatments are: a TCOD of $650-700 \mathrm{mg} / \mathrm{l}$, a TBOD 5 of 15-22 mg/l, a TN of $90 \mathrm{mg} / \mathrm{l}$, a TP of $9 \mathrm{mg} / \mathrm{l}$, and SS of $50 \mathrm{mg} / \mathrm{l}$ (Dong 2003). This effluent quality is considered to be suitable for holding in the lagoon system for further treatment, reuse/disposal (Dong 2003) on this farm.

Currently, a pilot plant, including two $10 \mathrm{~m}^{3}$ of anaerobic Bio-nest reactors with a $3.8 \mathrm{~m}^{3}$ of aerobic EMMC reactor, was installed and operated in this dairy farm in order to determine a set of design and operation criteria for the potential integration of existing wastewater renovation/ reuse systems in order to meet the developed environment policy and improve the agriculture production system.

\section{Approach/procedure}

\section{Reactor system of pilot plant}

A pilot plant for treating milk parlor wastewater and reuse consisted of a primary settling/equalization tank, two anaerobic reactors, an intermediate holding tank, and an aerobic reactor. The pilot plant layout and configurations of the bioreactors are depicted in Figs. 1 and 2, respectively.

The primary settling/equalization tank of $16.7 \mathrm{~m}^{3}$ was used to overcome the operational problems and to improve the performance of the downstream process by the preremoval of high concentrated solids and reduce the shockloading caused by variations in the influent wastewater strength. This tank is compartmentalized into two zones for better solids settling. Raw wastewater goes into the first zone, allowing grit/heavy solids to settle on the bottom. The wastewater then goes into the second zone. A submerged pump for providing wastewater to the anaerobic reactor is placed at a height of $0.7 \mathrm{~m}$ from the bottom of the settling tank.

Two anaerobic reactors were made with isophthalic polyester (Harrington Industrial Plastics LLC). Each reactor had a volume of $10 \mathrm{~m}^{3}$, inside diameter of $183 \mathrm{~cm}$ and depth of $381 \mathrm{~cm}$. The water volume of each reactor was about $8.4 \mathrm{~m}^{3}$. In order to evenly distribute influent wastewater to the Bio-nest reactor, 12 feed holes of 0.75 diameter were made on both sides of the inlet feeding PVC pipe and were placed at the bottom of the tank. Two layers

Table 1 New treatment target criteria

\begin{tabular}{llllll}
\hline Category & TCOD & Nitrogen $(\mathrm{TN})$ & Phosphorous $(\mathrm{P})$ & SS & Effluent pH \\
\hline Target concentration & $650-700 \mathrm{mg} / \mathrm{l}$ & $70-80 \mathrm{mg} / \mathrm{l}$ & $6-10 \mathrm{mg} / \mathrm{l}$ & $5-8 \mathrm{mg} / \mathrm{l}$ & $6.5-8.5$ \\
Target reduction efficiency & $85-90 \%$ & $60-65 \%$ & $50-70 \%$ & $97-99 \%$ & \\
\hline
\end{tabular}

Source: Dong (2003) 


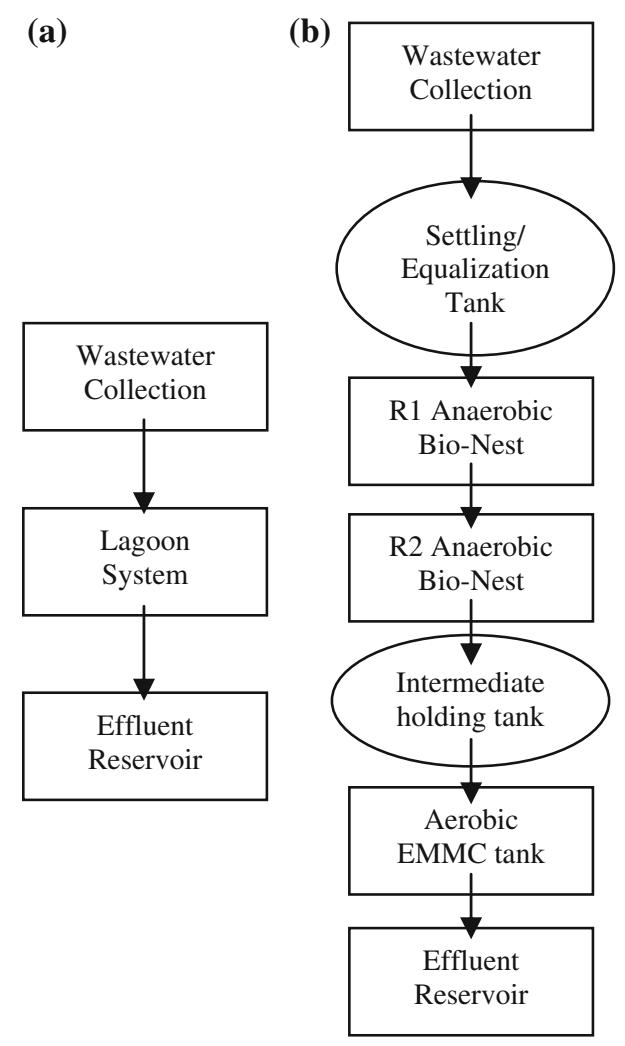

Fig. 1 Layout of pilot plant process compared to existing treatment system. (a) Existing treatment system. (b) Bio-nest reactor

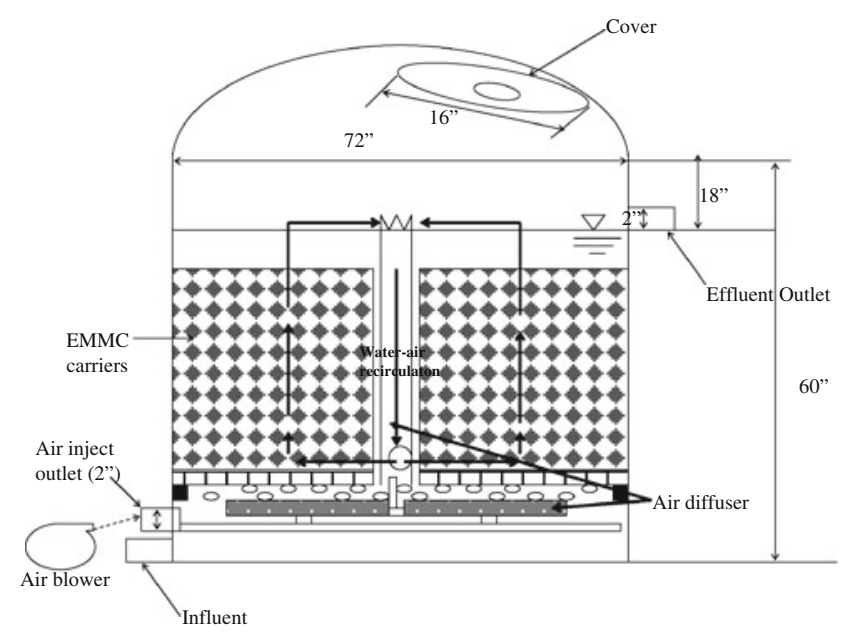

(d) EMMC reactor

Fig. 2 Configuration of aerobic EMMC-reactor

of "plastic string" (referred as Bio-nest) are the media and were placed into each anaerobic reactor in order to increase the retention time of the biomass (Fig. 3). The Bio-nest media is made of PVC and physically occupies $19 \%$ of the bioreactor, provides a measured void volume of $98.6 \%$, and a media packing ratio of $1.4 \%$. Each reactor has three sampling ports at $0.38,1.6$, and $3.2 \mathrm{~m}$ height from the

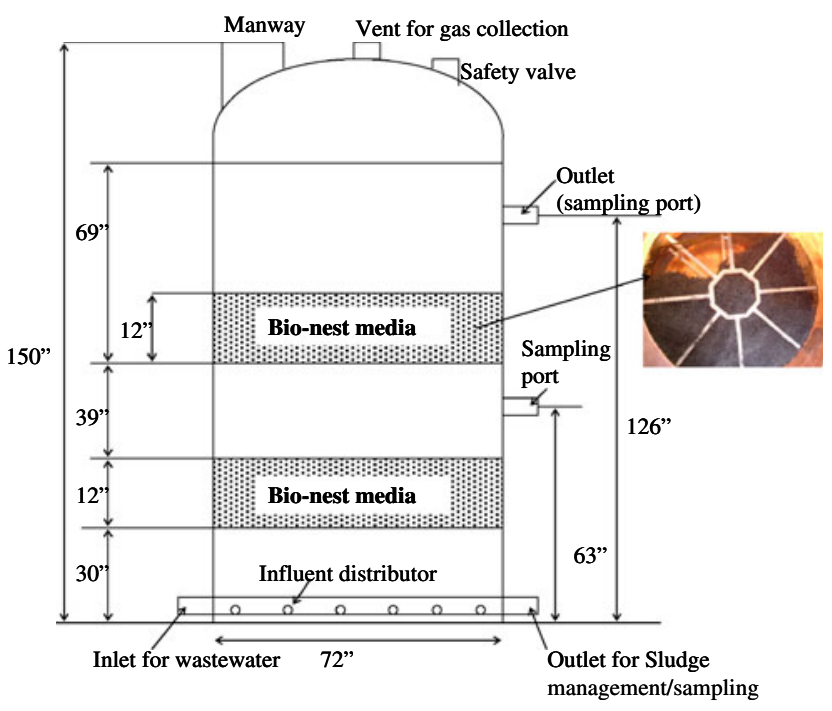

(b) Bio-nest reactor

Fig. 3 Configuration of anaerobic Bio-nest reactor

reactor bottom. If necessary, sludge can be discarded through the sludge wasting outlet at the bottom of the reactor. On top of each reactor is a vent for gas collection and a safety valve. Two gas meters (Measurement Control Systems, AM-250) were installed to measure the biogas from each Bio-nest anaerobic reactor to separately collect gas and analyze its composition. The separation of gas can also enhance the bioreactor stability since it can protect syntrophic bacteria from elevated levels of hydrogen that are mostly produced in the first anaerobic Bio-nest bioreactor. An iron sponge was placed inside of the pipeline prior to the gas meter to prevent corrosion.

For the intermediate holding tank, the domed vertical tank of $1.89 \mathrm{~m}^{3}$ (Mr. Sandman, Inc., Moldel\#JS-120) with a $119 \mathrm{~cm}$ inside diameter and $183 \mathrm{~cm}$ depth was placed between the second "Bio-nest" reactor and the aerobic EMMC reactor. The overflow can be discharged to the lagoon. Part of the effluent suspended solids from the Bionest reactor settled in the intermediate tank before going to the aerobic EMMC reactor.

Start-up and operation of anaerobic Bio-nest system

Two anaerobic Bio-nest reactors were seeded with the anaerobic sludge taken from an anaerobic digester at the Hawaii-American Water Company in Honolulu, Hawaii. The Bio-nest reactors were allowed to acclimate at an ambient temperature $\left(25-30^{\circ} \mathrm{C}\right)$ without feeding for approximately 2 weeks. Thereafter, about $3.8 \mathrm{~m}^{3}$ of wastewater was fed in an up-flow pattern into the Bio-nest reactors biweekly at an HRT (hydraulic retention time) of 15 days. 
Table 2 Performance of Bio-nest system at OLR of $1.5 \mathrm{~g} / \mathrm{l} / \mathrm{day}$

\begin{tabular}{lllll}
\hline & $\begin{array}{l}\text { Primary } \\
\text { efficiency }\end{array}$ & $\begin{array}{l}\text { Bio-nest 1 } \\
\text { efficiency }\end{array}$ & $\begin{array}{l}\text { Bio-nest 2 } \\
\text { efficiency }\end{array}$ & $\begin{array}{l}\text { Removal } \\
(\%)\end{array}$ \\
\hline TCOD (mg/l) & 3,178 & 1,695 & 779 & 75.5 \\
SCOD (mg/l) & 1,207 & 596 & 443.3 & 63.3 \\
Biogas (1/l/day) & N/A & 0.64 & 0.15 & N/A \\
Methane (\%) & N/A & 63.7 & N/A & N/A \\
\hline
\end{tabular}

After the acclimation period, the Bio-nest system was started up at an organic loading rate (OLR) ${ }^{1}$ of about $1.5 \mathrm{~g} /$ 1/day at an HRT of 2 days. Feeding was intermittently applied at a schedule of $1 \mathrm{~h}$ on/off to provide effective biomass and substrate mixing and to prevent the biomass from washing out. The equalization/settling tank removed about $28 \%$ of TCOD and $30 \%$ of SS. The operation results obtained for 25 days are shown in Table 2. The removal efficiency is calculated based on the effluent of the primary settling/equalization tank. Most of the biogas was produced from the first Bio-nest reactor. This indicates that anaerobic degradation of organics involving hydrolysis/acidification and acetogenesis/methanogenesis mainly takes place in the first Bio-nest reactor due to the low organic loading rate. The increase of the organic loading rate was followed for the experiment.

\section{Operation conditions}

The operational conditions for the two stage Bio-nest reactors are presented as follows:

\section{- Two stage anaerobic Bio-nest reactor}

Wastewater feeding schedule: $1 \mathrm{~h}$ on/ $1 \mathrm{~h}$ off.

HRT: $48 \mathrm{~h}\left[1.948 \mathrm{~kg} /\left(\mathrm{m}^{3}\right.\right.$ day $\left.)\right]$ and $36 \mathrm{~h}[2.538 \mathrm{~kg} /$ $\left(\mathrm{m}^{3}\right.$ day $\left.)\right]$

$27 \mathrm{~h}\left[0.967 \mathrm{~kg} /\left(\mathrm{m}^{3}\right.\right.$ day $\left.)\right], 21.7 \mathrm{~h}\left[1.446 \mathrm{~kg} /\left(\mathrm{m}^{3}\right.\right.$ day $\left.)\right]$ and $24.5 \mathrm{~h}\left[0.985 \mathrm{~kg} /\left(\mathrm{m}^{3}\right.\right.$ day $\left.)\right]$

$16 \mathrm{~h}$ operation with $8 \mathrm{~h}$ feeding in a day

\section{- EMMC-biobarrel reactor}

Continuous feeding schedule

HRT: $12.3 \mathrm{~h}$

Intermittent aeration at time schedule of $1 \mathrm{~h}$ on/ $1 \mathrm{~h}$ off.

\section{Sampling and chemical analysis}

The samples were collected from the input (feed) and output (digested effluent) of the primary equalization/settling tank, each stage anaerobic Bio-nest reactor, aerobic EMMC reactor, the intermediate holding tank, and the EMMC-biobarrel reactor at a frequency of three times per

${ }^{1} \mathrm{OLR}=[\mathrm{COD}]_{\mathrm{in}} / \mathrm{HRT}$ week for the chemical analysis of total solid (TS), total volatile solid (TVS), total suspended solid (TSS), total volatile suspended solid (TVSS), total chemical oxygen demand (TCOD), soluble COD (SCOD), total nitrogen $(\mathrm{TN}), \mathrm{NH}_{3}-\mathrm{N}, \mathrm{pH}$. Additionally, the samples from the EMMC-biobarrel reactor were analyzed for $\mathrm{NO}_{2}-\mathrm{N}$ and $\mathrm{NO}_{3}-\mathrm{N}$. The TS, TVS, TSS, TVSS, TCOD, SCOD, TN, the $\mathrm{NH}_{3}-\mathrm{N}$ analysis was conducted following the standard method (APHA 1989). The $\mathrm{NO}_{2}-\mathrm{N}$ analysis was conducted following the $\mathrm{HACH}$ diazotization method. The $\mathrm{NO}_{3}-\mathrm{N}$ analysis was conducted following the $\mathrm{HACH}$ cadmium reduction method (Hach 1992). The $\mathrm{pH}$ was measured by using the Orion $501 \mathrm{pH}$ analyzer.

\section{Results and discussion}

\section{Characteristics of raw wastewater}

The characteristics of milk parlor wastewater in this study were primarily separated into two sets. The first set of samples was collected between the starting date and the 105th day of operation. The second set of the samples was collected between the 105th and 270th day of the operation.

The relationship between wastewater TCOD and SCOD between the starting date and the 105th day of operation is presented in Fig. 4.

The relationship is defined as

$\mathrm{SCOD}=0.3417(\mathrm{TCOD}), \mathrm{mg} / 1$

A value of the coefficient of determination, $R$ squared $=0.745$ indicates that it is a moderate fit.

The relationship between wastewater TCOD and SCOD between the 105th and 170th day of operation is presented in Fig. 5.

The relationship is defined as:

$\mathrm{SCOD}=0.261(\mathrm{TCOD}), \mathrm{mg} / 1$

A value of the coefficient of determination, $R$ squared $=0.6101$ indicates that it is a moderate fit too.

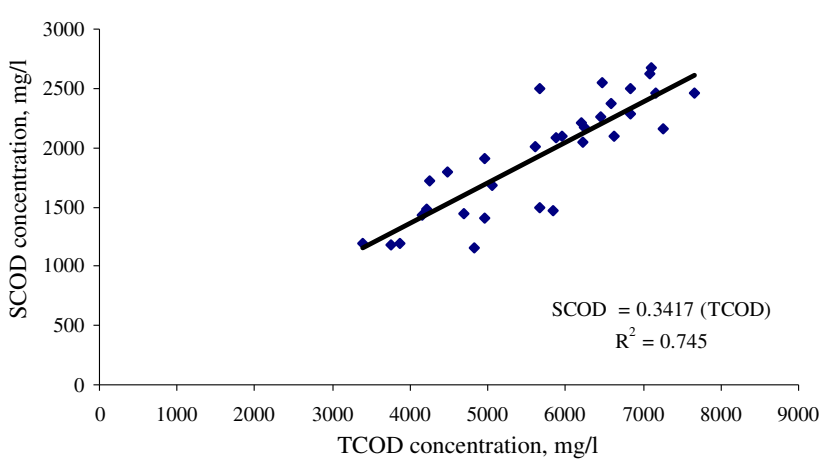

Fig. 4 TCOD and SCOD relationship between 1st and 105th days of operation 


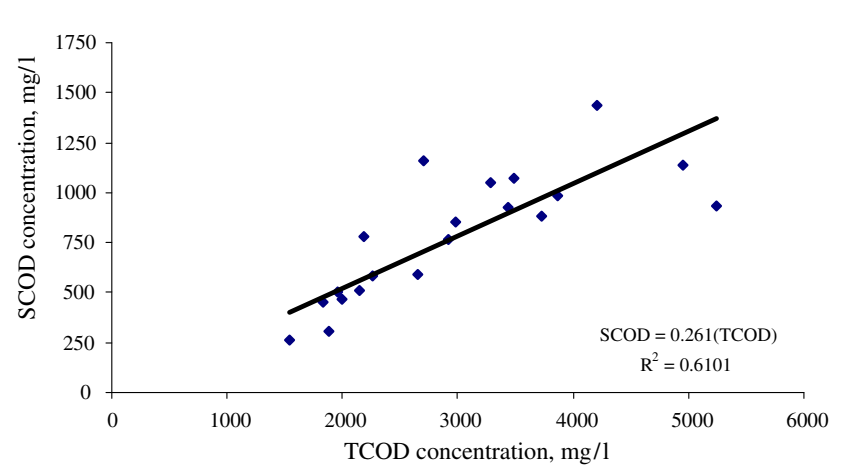

Fig. 5 TCOD and SCOD relationship between 105th and 170th days of operation

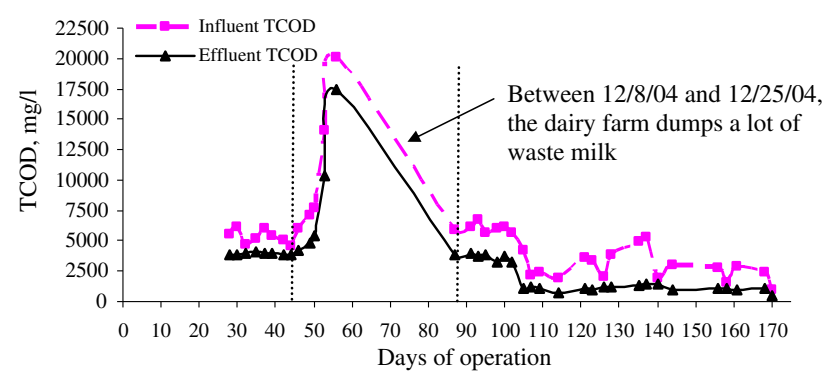

Fig. 6 TCOD of influent and effluent of the primary settling/ equalization tank

Moreover, the characteristics of milk parlor wastewater for both study periods are presented in Fig. 6. The function of the primary settling/equalization tanks is working as presented in Fig. 6, measured as TCOD. The increase in TCOD between day 50 and day 90 were due to accidental milk dumping by the farmer, and the effect of the increased shock loads was not the focus of this investigation. This effluent is planned to be fed to the two anaerobic reactors (R1 and R2).

Process performance of Bio-nest bioreactor

Overall, TCOD removal rate and biogas production rate based on different HRT and TCOD loading rates are presented in Tables 3 and 4, respectively.

As shown in Table 2, the HRT of R1 equals to R2, which is half the HRT of a two-stage Bio-nest bioreactor based on liquid volume of the bioreactors. The average TCOD loading rate of $\mathrm{R} 1$ is increased from 3.899 to $5.076 \mathrm{~g} / \mathrm{l} /$ day when HRT is reduced from 48 to $36 \mathrm{~h}$, with a high average influent TCOD concentration. Consequently, the TCOD removal rate of R1 increases from 2.204 to $2.636 \mathrm{~g} / \mathrm{l} / \mathrm{day}$. The system was able to absorb and perform better in the event of increased organic loads.

The average TCOD loading rate of $\mathrm{R} 2$ is in the range of $0.760-2.439 \mathrm{~g} / \mathrm{l} /$ day with an HRT between 22 and $48 \mathrm{~h}$. Theoretically, the TCOD removal capacity of R2 should be equal to the $\mathrm{R} 1$ capacity because the physical conditions of the $\mathrm{R} 2$ bioreactor are similar to $\mathrm{R} 2$ if the wastewater input is similar to the wastewater input for R1. However, the wastewater input for R2 is partially treated from R1. The treatment capacity for R2 may be different from R1. Further study is required to confirm this capacity.

As shown in Table 3, the biogas production rate from $\mathrm{R} 1$ is in the range of $0.138-0.505 \mathrm{1} / \mathrm{l} /$ day (overall HRT of $21.7-48 \mathrm{~h}$ ). The methane content of the biogas from R1 varies in the range of $49.3-80.9 \%$. The biogas production rate from $\mathrm{R} 2$ is in the range of $0.049-0.0971 / 1 /$ day. The methane content of the biogas from $\mathrm{R} 2$ varies in the range of $65.5-81.1 \%$. The average biogas production rate of the two-stage Bio-nest is in the range of $0.187-0.573 \mathrm{1} / \mathrm{l} / \mathrm{day}$.

$\mathrm{R} 1$ is the main contributor in the two-stage Bio-nest bioreactor or total produced biogas in the system (60-88\% biogas production). The biogas production rate is dependent on the HRT applied when the average influent TCOD concentration is almost the same. For example, the biogas production rate is decreased from 0.573 to $0.476 \mathrm{l} / \mathrm{l} /$ day when the HRT is decreased from 48 to $36 \mathrm{~h}$ with the average influent TCOD concentration in the range of 3,807-3,899 mg/l.

Also, the biogas production rate decreased from 0.278 to $0.187 \mathrm{l} / \mathrm{l} /$ day when the HRT was decreased from 27 to $25 \mathrm{~h}$ with an average influent TCOD concentration ranging from, 1,005 to $1,093 \mathrm{mg} / \mathrm{l}$. Instead of depending on the HRT and influent TCOD concentration individually, the organic loading rate based on the ratio between TCOD:HRT is used to estimate the biogas production rate for R1 and the two-stage Bio-nest bioreactor (R1 + R2), which are presented in Figs. 7 and 8. This will be further used to develop the design/operation criteria and economic evaluation.

\section{Process performance for EMMC reactor}

In order to better reuse the anaerobically treated effluent from the Bio-nest reactor, the aerobic EMMC-biobarrel process is followed. The anaerobic-treated wastewater from the two-stage Bio-nest bioreactor that is retained in the IHT is continuously pumped to the aerobic EMMCbiobarrel bioreactor.

The aerobic EMMC-biobarrel process consists of an aerobic EMMC-biobarrel bioreactor and a clarifier tank. The main function of the aerobic EMMC-biobarrel bioreactor is to remove the remaining nutrient and oxygen demand materials from the anaerobic two-stage Bio-nest process treated wastewater. The effluent from the EMMCbiobarrel bioreactor is passed on to the clarifier tank to retain the final effluent of the treatment system. The overall results of the aerobic EMMC-biobarrel process regarding the TCOD loading rate and removal efficiency is shown in 
Table 3 TCOD loading rate and removal rate of R1, R2, and R1 $+\mathrm{R} 2+\mathrm{H}$ at various HRT

\begin{tabular}{|c|c|c|c|c|c|c|c|c|}
\hline Period & $\begin{array}{l}\text { HRT of } \\
\text { two-stage } \\
\text { Bionest (h) }\end{array}$ & $\begin{array}{l}\text { HRT of R1 } \\
\text { and R2 (h) }\end{array}$ & $\begin{array}{l}\text { Average TCOD } \\
\text { loading rate of } \\
\text { two-stage Bio-nest } \\
\text { (g/l/day) }\end{array}$ & $\begin{array}{l}\text { Average. } \\
\text { TCOD loading } \\
\text { rate of } \mathrm{R} 1 \\
(\mathrm{~g} / \mathrm{l} / \text { day })\end{array}$ & $\begin{array}{l}\text { Average TCOD } \\
\text { loading rate of } \\
\mathrm{R} 2 \text { (g/l/day) }\end{array}$ & $\begin{array}{l}\text { Average TCOD } \\
\text { removal rate of } \\
\text { two-stage Bio-nest } \\
(\mathrm{g} / \mathrm{l} / \text { day })\end{array}$ & $\begin{array}{l}\text { Average TCOD } \\
\text { removal rate of } \\
\mathrm{R} 1 \text { (g/l/day) }\end{array}$ & $\begin{array}{l}\text { Average TCOD } \\
\text { removal rate of } \\
\mathrm{R} 2(\mathrm{~g} / \mathrm{l} / \text { day })\end{array}$ \\
\hline 1 & 48.0 & 24.0 & 1.949 & 3.899 & 1.695 & 1.424 & 2.204 & 0.645 \\
\hline 2 & 36.0 & 18.0 & 2.538 & 5.076 & 2.439 & 1.708 & 2.636 & 0.781 \\
\hline 3 & 27.1 & 13.6 & 0.967 & 1.934 & 0.760 & 0.679 & 1.175 & 0.184 \\
\hline 4 & 24.5 & 12.3 & 0.985 & 1.970 & 0.802 & 0.652 & 1.168 & 0.136 \\
\hline 5 & 21.7 & 10.8 & 1.446 & 2.891 & 1.573 & 1.052 & 1.318 & 0.786 \\
\hline
\end{tabular}

Table 4 Biogas production rate of R1, R2, and R1 + R2 at various HRT

\begin{tabular}{|c|c|c|c|c|c|c|c|c|}
\hline Period & $\begin{array}{l}\text { HRT of } \\
\text { two-stage } \\
\text { Bionest (h) }\end{array}$ & $\begin{array}{l}\text { Average biogas } \\
\text { production rate } \\
\text { of } \mathrm{R} 1 \text { ( } 1 / 1 / \text { day) }\end{array}$ & $\begin{array}{l}\text { Average biogas } \\
\text { production rate } \\
\text { of } \mathrm{R} 2 \text { ( } 1 / 1 / \text { day) }\end{array}$ & $\begin{array}{l}\text { Average biogas } \\
\text { production rate of } \\
\text { Bio-nest (1/1/day) }\end{array}$ & $\begin{array}{l}\text { Average gas } \\
\text { quality of } \mathrm{R} 1 \\
\text { (\% methane) }\end{array}$ & $\begin{array}{l}\text { Average gas } \\
\text { quality of R2 } \\
\text { (\% methane) }\end{array}$ & $\begin{array}{l}\text { Percentage } \\
\text { of biogas produced } \\
\text { from R1 }(\%)\end{array}$ & $\begin{array}{l}\text { Percentage } \\
\text { of biogas } \\
\text { produced } \\
\text { from R2 (\%) }\end{array}$ \\
\hline 1 & 48.0 & 0.505 & 0.067 & 0.573 & 64.7 & 68.9 & 88 & 12 \\
\hline 2 & 36.0 & 0.379 & 0.097 & 0.476 & 69.5 & 71.4 & 80 & 20 \\
\hline 3 & 27.1 & 0.167 & 0.085 & 0.278 & 76.3 & 78.1 & 60 & 30 \\
\hline 4 & 24.5 & 0.138 & 0.049 & 0.187 & 78.1 & 79.7 & 74 & 26 \\
\hline 5 & 21.7 & 0.180 & 0.054 & 0.235 & 77.0 & 74.5 & 77 & 23 \\
\hline
\end{tabular}

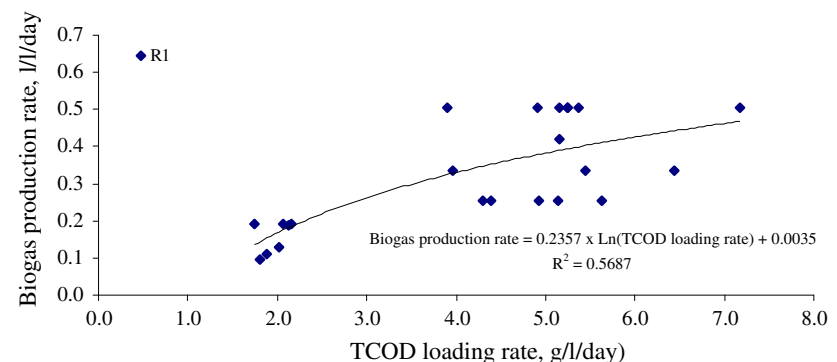

Fig. 7 Relationship between TCOD loading rate and biogas production rate of $\mathrm{R} 1$ in the steady state

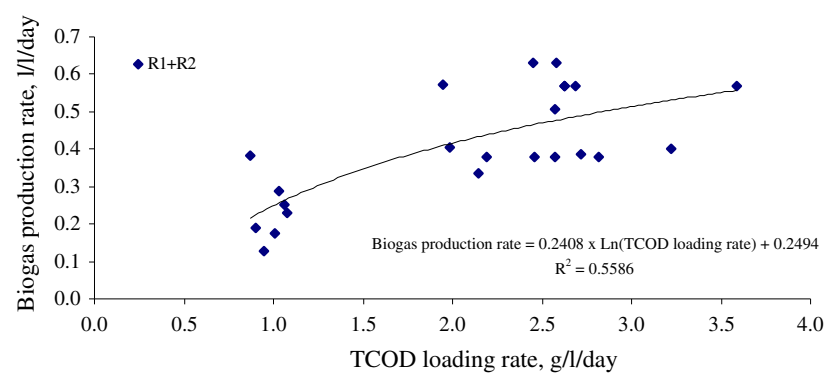

Fig. 8 Relationship between TCOD loading rate and biogas production rate of $\mathrm{R} 1+\mathrm{R} 2$ in the steady state

Fig. 9. As the TCOD loading rate is maintained in the range of $0.51-0.92 \mathrm{~g} / \mathrm{l} / \mathrm{day}$, the TCOD removal efficiency is in the range of 43-68\%. Similarly, the TN removal efficiency of $11-37 \%$ can be achieved when the TN loading rate is maintained in the range of $0.16-0.23 \mathrm{~g} / \mathrm{l} / \mathrm{day}$, as shown in

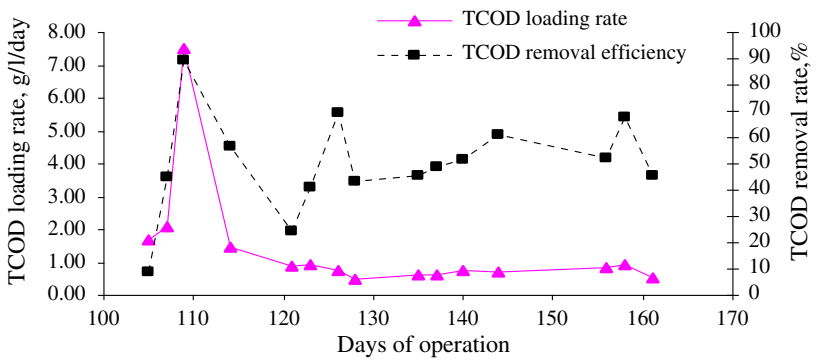

Fig. 9 The overall TCOD loading rate and removal efficiency of the EMMC-biobarrel process at HRT $12.3 \mathrm{~h}$

Fig. 10. As for improving the TN removal, many factors are suggested by our previous studies (Cho et al. 2007; Yang et al. 1997, 2002a, b, 2003a, b), such as C/N ratio, aeration/ non-aeration time, and HRT. In this study, the power limit of the air blower restricts longer aeration times, which restricted the oxidation of $\mathrm{NH}_{4}-\mathrm{N}$ to $\mathrm{NO}_{3}-\mathrm{N}$. This consequently further limits the denitrification efficiency. Thus, the improving TN removal is limited for this study.

Integrated Bio-nest and EMMC-biobarrel process

The effluent concentrations of TCOD, TN, and TSS of the overall integration of Bio-nest and EMMC processes are presented in Figs. 11, 12 and 13, respectively. The TCOD loading rates ranged between 0.62 and 1.06 g/l/day. Furthermore, the removal efficiencies range for TCOD, TN, and TSS are $83-88,40$, and $90-96 \%$. The TN removal is 


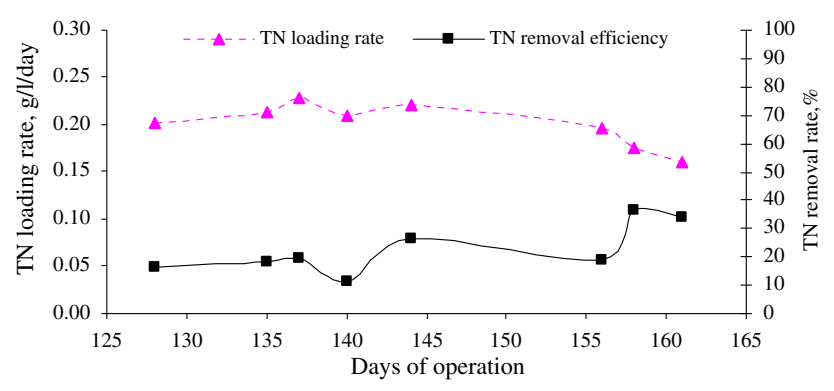

Fig. 10 TN loading rate and removal efficiency of the EMMCbiobarrel process with HRT $12.3 \mathrm{~h}$

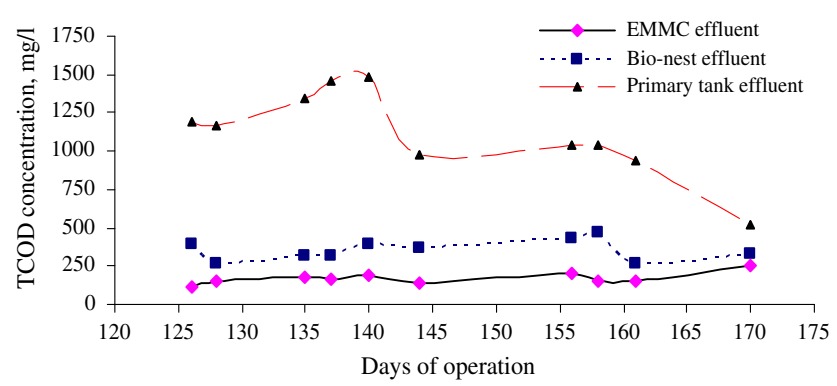

Fig. 11 TCOD of the integrated Bio-nest and EMMC-biobarrel process

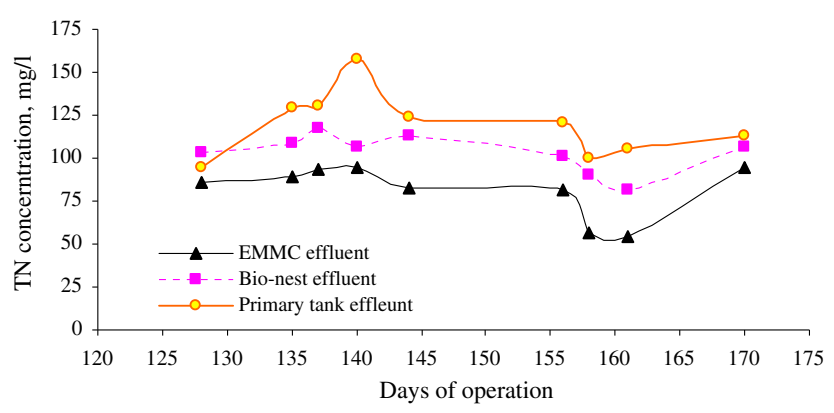

Fig. $12 \mathrm{TN}$ of the integrated Bio-nest and EMMC-biobarrel process

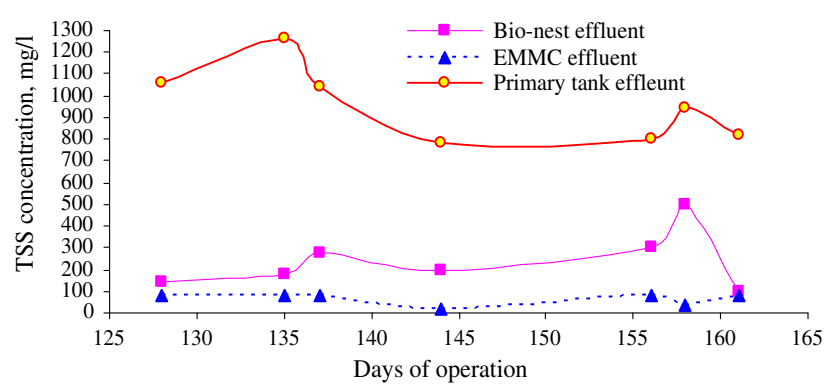

Fig. 13 TSS of the integrated Bio-nest and EMMC-biobarrel process

heavily dependent on the degree of nitrification/denitrification, available external carbon source, and aeration schedule. This can be adjusted through the need of the requirement for reuse/disposal of the treated effluent.
Design and operation criteria

\section{For medium strength wastewater}

In general, the design and operation criteria are directly dependent upon two factors: the characteristics of the wastewater and the desired quality of the final effluent. Results from laboratory tested determined the milk parlor wastewater characteristics between medium strength wastewater and diluted wastewater generated at the dairy farm. The average TCOD of medium strength raw milk parlor wastewater was $5,660 \pm 593 \mathrm{mg} / \mathrm{l}$.

Consequently, the average TCOD concentration of influent from the Bio-nest biobarrel is decreased to $3,802 \pm 246 \mathrm{mg} / \mathrm{l}$ after it passes through the primary settling/equalization tank. Therefore, this average TCOD concentration is used in quantifying the design operation criteria of the studied bioreactor.

The quality of the final effluent from the studied bioreactor is dependent on the further usage objectives for the treated effluent. For this study, the final effluent of the bioreactor is proposed to be reused as floor flushing water after integrating with the existing lagoon system for further treatment. As suggested by Dong (2003), the TCOD concentration of $650 \mathrm{mg} / \mathrm{l}$ is used as the target TCOD for this design and operational criteria. The expected influent and effluent TCOD and HRT of both the anaerobic Bio-nest and the EMMC-biobarrel processes were estimated from observed relationship between TCOD loading rate and biogas production rate from Fig. 8. And the expected influent and effluent TCOD and HRT values are summarized in Table 5 for an effluent target TCOD $<650 \mathrm{mg} / \mathrm{l}$.

The HRT applied for the anaerobic Bio-nest and the EMMC-biobarrel processes are 15 and $12 \mathrm{~h}$, respectively. In addition, the biogas production rate of $0.6841 / 1 /$ day is expected from the anaerobic Bio-nest bioreactor.

However, if the farmer wanted to achieve a target effluent TCOD concentration of $350 \mathrm{mg} / \mathrm{l}$, then the design and operational criteria of the expected influent and effluent TCOD, and HRT of both the anaerobic Bio-nest and the EMMC-biobarrel processes are estimated and summarized in Table 6. The prediction was estimated from the observed relationship between TCOD loading rate and biogas production rate from Fig. 8.

As a result, the HRT applied for the anaerobic Bio-nest and two-stage EMMC-biobarrel processes are 15 and $18 \mathrm{~h}$, respectively. Also, the biogas production rate of 0.684 1/1/ day is expected from the anaerobic Bio-nest bioreactor.

\section{For dilute wastewater}

Similarly, the design and operational criteria of the studied bioreactor for dilute milk parlor wastewater are estimated 
Table 5 Criteria for medium strength wastewater with the target TCOD $<650 \mathrm{mg} / \mathrm{l}$

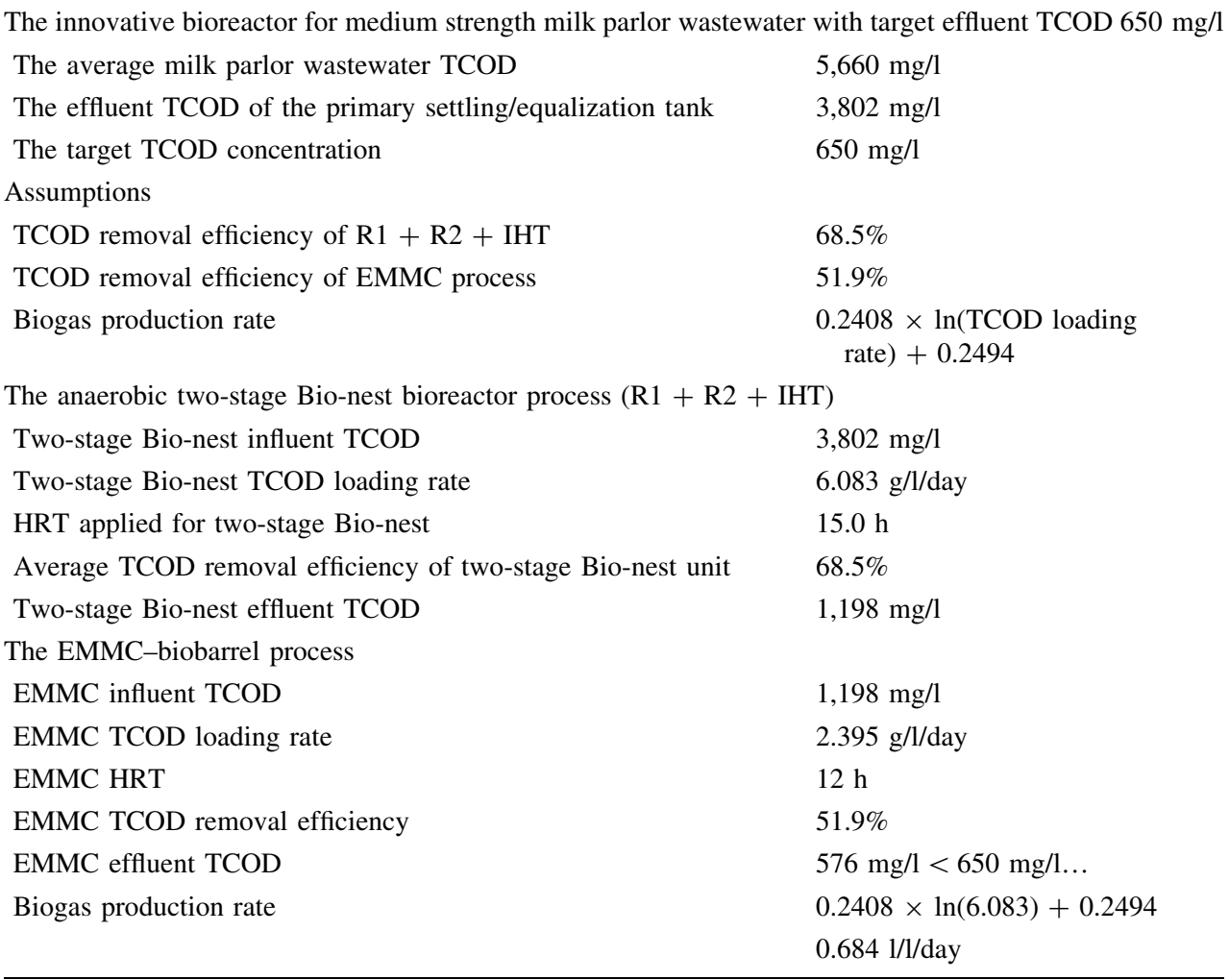

using the same procedures presented for the medium strength wastewater. A TCOD of $2,899 \mathrm{mg} / \mathrm{l}$ of dilute raw milk parlor wastewater was used for the criteria development. Consequently, the average TCOD concentration of influent from the Bio-nest bioreactor is decreased to $1,314 \mathrm{mg} / \mathrm{l}$ after passing through the primary settling/ equalization tank. Therefore, this average TCOD concentration is used for quantifying the design and operational criteria of the innovative bioreactor. The expected influent and effluent TCOD and HRT of the anaerobic Bio-nest are estimated and summarized in Table 7. The anaerobic single-tank Bio-nest bioreactor with an HRT of $7.5 \mathrm{~h}$ is applied and the primary settling/equalization tank is still used to handle the dilute milk parlor wastewater when the desired target TCOD concentration is $<650 \mathrm{mg} / \mathrm{l}$.

On the other hand, when the aerobic EMMC-biobarrel is added to the system for further treatment to enhance the anaerobically treated wastewater, the effluent can meet more stringent requirements of $<350 \mathrm{mg} / \mathrm{l}$ of TCOD discharge concentration. The expected influent and effluent TCOD and HRT of both the anaerobic Bio-nest and the aerobic EMMC-biobarrel are estimated and summarized in Table 8 .

In summary, the pollution strength of milk parlor wastewater and the target effluent TCOD are the two key factors that influence the wastewater treatment system. In this study, the operational performances of the anaerobic
Bio-nest and aerobic EMMC-biobarrel process were investigated and analyzed. The performance equations of the anaerobic Bio-nest bioreactor developed in this study were used as a basis to develop the design and operational criteria for the anaerobic Bio-nest bioreactor. The operational performances of the EMMC-biobarrel process with a $12.5 \%$ packing ratio and intermittent aeration schedule were used as the basis to develop the design and operational criteria of the EMMC-biobarrel bioreactor.

\section{Economic evaluation}

A detailed economic evaluation of the integrated treatment system was developed (Kongsil 2006). In order to illustrate the cost of treatment and the economic potential of the integrated bioreactor at various levels of target effluent quality, three levels of target effluent TCOD $(<1,200,650$, and $350 \mathrm{mg} / \mathrm{l})$ were assigned. The construction, operation, and maintenance cost of operating the dairy farm of 960 cows were used to determine economical decision factors. Economical factors determined include: net present worth (NPW), annual worth (AN), and average annual treatment cost per ton of TCOD removal. These factors were used as indicators to illustrate the efficiency of the reactors. The results are presented in Tables 9 and 10 for the medium and dilute strength milk parlor wastewater, respectively. 
Table 6 Criteria for medium strength wastewater with the target TCOD $<350 \mathrm{mg} / \mathrm{l}$
Table 7 Criteria for dilute wastewater with the target TCOD $<650 \mathrm{mg} / \mathrm{l}$
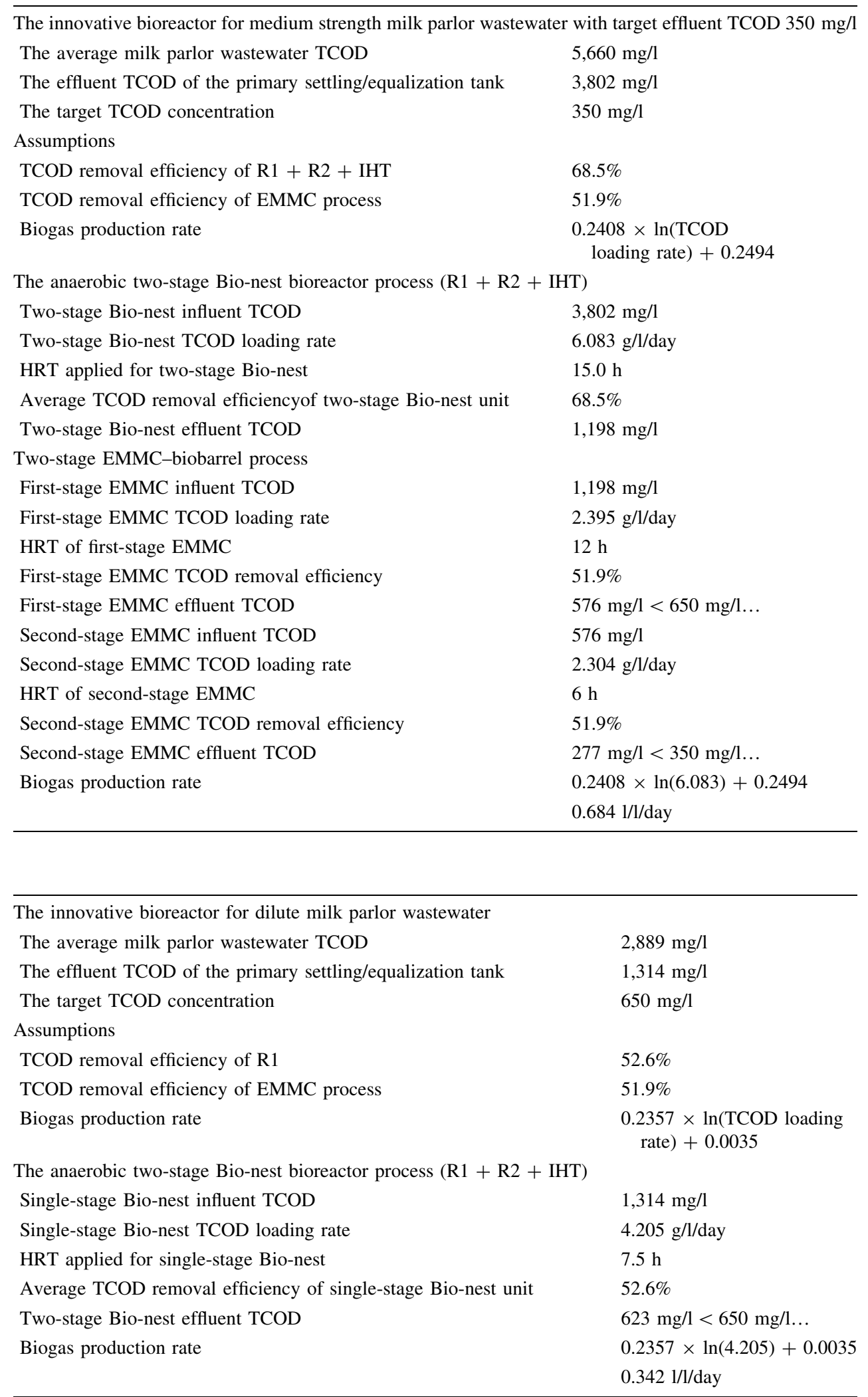

The economic information evaluated along with field data enables the dairy producers to determine the optimal treatment options (treat medium strength or dilute strength milk parlor wastewater) that should be followed to meet their effluent reuse requirement. Based upon our study, the existing lagoon system cannot achieve the suggested target 
Table 8 Criteria for dilute wastewater with the target TCOD $<350 \mathrm{mg} / \mathrm{l}$
Table 9 Summary of NPW, AW, and the average treatment cost for medium strength milk parlor wastewater

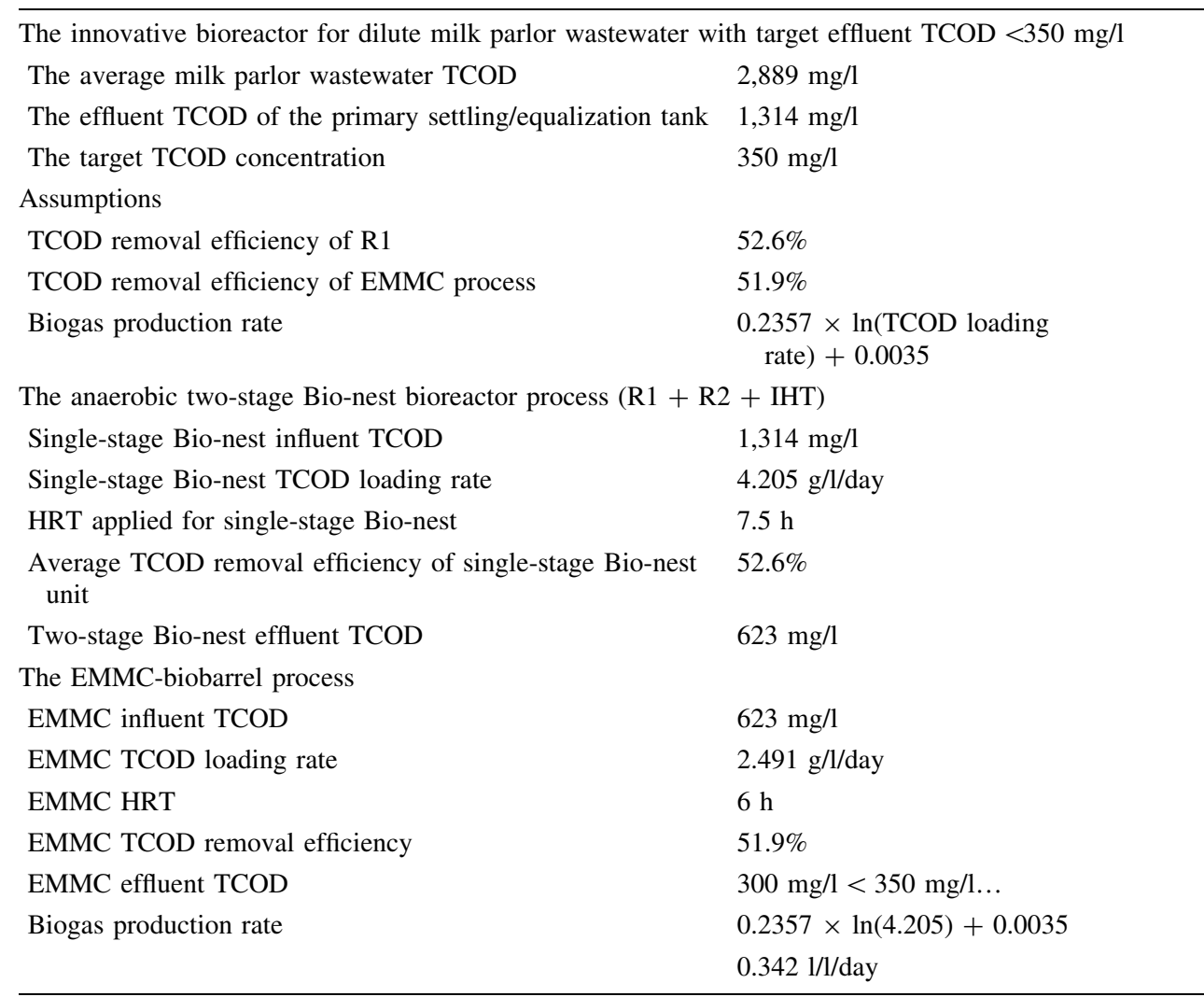

NPW of the innovative bioreactor at target effluent TCOD $\sim 1,198 \mathrm{mg} / \mathrm{l}$

$\$ 61,071$

NPW of the innovative bioreactor at target effluent TCOD $\sim 576 \mathrm{mg} / \mathrm{l}$

$-\$ 554,940$

NPW of the innovative bioreactor at target effluent TCOD $\sim 277 \mathrm{mg}$ /

$-\$ 882,857$

AW of the innovative bioreactor at target effluent TCOD $\sim 1,198 \mathrm{mg} / \mathrm{l}$

$\$ 5,217$

AW of the innovative bioreactor at target effluent TCOD $\sim 576 \mathrm{mg} / \mathrm{l}$

$-\$ 47,405$

AW of the innovative bioreactor at target effluent TCOD $\sim 277 \mathrm{mg} / \mathrm{l}$

$-\$ 75,417$

Average annual cost of the treatment per ton of removal TCOD at target

$-\$ 9.865$

effluent TCOD $\sim 1,198 \mathrm{mg} / \mathrm{l}$

Average annual cost of the treatment per ton of removal TCOD at

target effluent TCOD $\sim 576 \mathrm{mg} / \mathrm{l}$

Average annual cost of the treatment per ton of removal TCOD at target effluent TCOD $\sim 277 \mathrm{mg} / \mathrm{l}$
Table 10 Summary of NPW, $\mathrm{AW}$, and the average treatment cost for dilute milk parlor wastewater

\begin{tabular}{ll}
\hline NPW of the innovative bioreactor at target effluent TCOD $\sim 623 \mathrm{mg} / \mathrm{l}$ & $-\$ 386,312$ \\
NPW of the innovative bioreactor at target effluent TCOD $\sim 300 \mathrm{mg} / \mathrm{l}$ & $-\$ 787,596$ \\
AW of the innovative bioreactor at target effluent TCOD $\sim 623 \mathrm{mg} / \mathrm{l}$ & $-\$ 33,000$ \\
AW of the innovative bioreactor at target effluent TCOD $\sim 300 \mathrm{mg} / \mathrm{l}$ & $-\$ 67,279$ \\
Average annual cost of the treatment per ton of removal TCOD at target & $\$ 235.159$ \\
effluent TCOD $\sim 623 \mathrm{mg} / \mathrm{l}$ & $\$ 326.713$ \\
Average annual cost of the treatment per ton of removal TCOD at target & \\
effluent TCOD $\sim 300 \mathrm{mg} / \mathrm{l}$ &
\end{tabular}

effluent reuse requirements in Hawaii (Dong 2003). However, the integrated Bio-nest and EMMC system is shown in a pilot scale to treat the wastewaters at various suggested effluent standards. The economic analysis showed that it would be cheaper to use medium strength rather dilute strength milk parlor wastewater as influent. This is because the increased biogas and other benefits reduce the overall operational and maintenance cost. 


\section{Conclusion}

A pilot plant study examined the possibilities for a dairy farmer on the island of O'ahu to better manage treated wastewater for reuse from their existing lagoon system. In situ pretreatment biological reactors, including anaerobic Bio-nest and aerobic EMMC reactors were installed in the field. Integrating these two bioreactors achieved at steady state an overall TCOD removal efficiency of $85-95 \%$ at TCOD loading rates of $0.5-0.9 \mathrm{~g} / \mathrm{l} / \mathrm{day}$. At this loading rate the biogas can be produced at a rate of $0.176-0.736$ 1/1/day with an average methane gas content of $68 \%$. Evaluating various levels of wastewater strength, a design/operation criteria was developed in order to achieve the set level of target effluent TCOD as seen in the cost analysis provided. It was estimated that $\$ 1.10$ per 1,000 gallons $\left(3.8 \mathrm{~m}^{3}\right)$ of wastewater needs to be treated or $\$ 91$ for each ton of TCOD removal is expected. Since the Dairy Farm is located on an island, it faces unique challenges in upgrading existing wastewater treatment facilities. The integrated Bio-nest/EMMC is an especially attractive alternative treatment process compared to currently available technologies like covered lagoons, anaerobic digestion, and conventional aerobic biological treatment processes which all require large land capacity for installment and complicated operation. The proposed integrated design, however, requires less space and simple operation to achieve the regulation of wastewater discharge standards and reuse. Furthermore, problems plaguing the existing lagoon systems, such odor production, ground water contamination, sludge clean out, and disposal of lagoon treated waster, can be eliminated. The medium strength dairy wastewater was found to be the better substrate to be used as influent for the integrated system. It would cost $\$ 0.62$ to treat 1,000 gallons of milk parlor wastewater at the recommended levels by Dong (2003) for floor flushing or irrigation. Sustainable agriculture production and environmental quality can be maintained with the implementation of the biological pre-treatment process. Also, the regulatory agency will be able to develop the necessary environment policy and procedures for the renovation/ reuse regulations for dairy wastewater.

Acknowledgments This work was supported by the College of Tropical Agriculture and Human Resources, University of Hawaii at Manoa, and the funding provided by a grant from the Tropical and Subtropical Agriculture Research (T-STAR) program, USDA.

\section{References}

APHA (1989) Standard methods for the examination of water and wastewater, 17th edn. American Public Health Association, Washington

Cho ES, Zhu J, Yang PY (2007) Intermittently aerated EMMCbiobarrel (entrapped mixed microbial cell with bio-barrel) process for concurrent organic and nitrogen removal. J Environ Manage 84:257-265

Crook J, Surampalli RY (1996) Water reclamation and reuse criteria in the US. Water Sci Technol 33(10-11):451-562

Dong L, (2003) An integrated treatment and reuse system of dairy wastewater-a case study in the state of Hawai'i. MS Thesis, Department of Molecular Biosciences and Bioengineering, University of Hawaii at Manoa, Honolulu, HI

Dong L, and Yang PY (2003) Design and analysis of an anaerobic bioreactor for milk parlor wastewater treatment, presented at the Asian Waterqual, 19-23 October 2003, Bangkok, Thailand

EPA (1983) Design manual: municipal waste stabilization ponds, EPA 625/1-83-015

Hach (1992) Hach DR/3000 spectrophotometer manual. Loveland, Colorado, USA

Kongsil P (2006) Engineering and economic evaluation of innovative bioreactor for milk parlor waste water treatment/reuse, MS Thesis, University of Hawaii at Manoa, Honolulu, HI

Koppar A (2005) A psuedo-steady model for anaerobic bio-nest reactor for treatment of milk parlor wastewater, MS Thesis, Department of Molecular Biosciences and Bioengineering, University of Hawaii at Manoa, Honolulu, HI

Mara DD, Alabaster GP, Pearson HW, Mills SW (1992) Waste stabilization ponds: a design manual for Eastern Africa. Lagoon Technology International, Leeds

Maynard HE, Ouki SK, Williams SC (1999) Tertiary lagoons: a review of removal mechanisms and performance. Water Res 33(1):1-13

Pearson HW, Mara DD, Mills SW, Smallman DJ (1987) Factors determining algal populations in waste stabilization ponds and the influence of algae on pond performance. Water Sci Technol 19(12): 131-140

Yang PY, Chang CJ, Whalon SA (1991) An anaerobic/aerobic pretreatment of sugarcane mill wastewater for application of drip irrigation. Water Sci Technol 24:243-250

Yang PY, Zhang ZQ, Jeong BG (1997) Simultaneous removal of carbon and nitrogen using and entrapped-mixed-microbial-cell process. Water Res 31(10):2617-2625

Yang PY, Cao K, Kim SJ (2002a) Entrapped mixed microbial cell process for combined secondary and tertiary wastewater treatment. Water Environ Res 74:226-234

Yang PY, Shimabukuro M, Kim SJ (2002b) A pilot scale bioreactor using EMMC for carbon and nitrogen removal. Clean Technol Environ Policy 3:407-412

Yang PY, Chen HJ, Kim SJ (2003a) Integrating EMMC process for biological removal of carbon and nitrogen from dilute swine wastewater for agricultural reuse. Bioresour Technol 86:245-252

Yang PY, Su R, Kim SJ (2003b) EMMC process for combined removal of organics, nitrogen and odor producing substance. $\mathrm{J}$ Environ Manage 69:381-389 